\title{
Environmental Information Disclosure and Financial Performance - Empirical Evidence from Heavily Polluting Industries in China
}

\author{
Jianfei Shen ${ }^{1}$, and Yidan Chen ${ }^{1, *}$ \\ ${ }^{1}$ School of Economics and Management, North China Electric Power University, Beijing, 102206, China
}

\begin{abstract}
Focusing on the quality of corporate environmental accounting information disclosure (EID), this paper attempts to explore the impact of financial performance on environmental information disclosure. We take listed companies in Chinese heavily polluting industries as the research object, and construct a multiple regression model for data analysis via SPSS. According to Chinese practice, we divide the financial indicators into four areas: solvency, operating capacity, profitability and development capacity, and select four indicators to represent them. The empirical results show that net working capital, current asset turnover and equity growth rate are positively correlated with EID, and return on total assets is negatively correlated with EID. This result means that the solvency, operating ability and development ability in financial performance can promote the improvement of EID, but profitability cannot.
\end{abstract}

\section{Introduction}

Environmental accounting is one of the ways to solve the contradiction between human society and natural environment. If the value of ecological environment can be quantified and become a consideration for companies' economic decisions, then they have to consider the environmental cost and reduce environmental damage when carrying out economic activities. Information disclosure is one of the important contents of environmental accounting research. Since the mid-1980s, companies, academia, accounting regulators, and professional associations have paid increasing attention to this area [1].

As environmental factors are difficult to measure, environmental information disclosure is still voluntary. Enterprises have a lot of choices in terms of environmental information disclosure contents and disclosure channels, which makes the quality of environmental information uneven. Why do some companies disclose high-quality environmental information, while others are poor? Previous studies have found that many factors may lead to this situation, such as environmental performance [2], media attention [3], government regulation [4], and so on. The theoretical research and empirical research on environmental accounting information disclosure are extensive, but most of the studies are based on developed countries [1,5]. In addition, there is also great controversy about the relationship between financial factors and EID [6].

Therefore, this paper takes China as the research background, and uses the multiple regression model to test the relationship between financial performance and
EID. The authors hope to provide empirical evidence from China for the environmental accounting field.

\section{Hypothesis development}

Given that environmental factors are difficult to measure, corporate environmental information is mainly disclosed voluntarily. The cost-benefit comparison of environmental disclosure behaviour determines whether the company is willing to improve environmental disclosure quality or not. The cost of environmental information disclosure may appear in data collection, information audit, and intangible costs caused by negative information. The benefits of environmental disclosure are to establish an environmentally friendly corporate image, attract environmentally sensitive consumers, and build brand awareness. For companies with different financial strength, the benefits of environmental disclosure are basically the same, but the relative costs are quite different. For companies with stronger economic power, the financial burden caused by disclosure costs is smaller, so they will have a higher benefit-cost ratio when disclosing environmental information. In other words, companies with more economic resources will make more extensive disclosures [7]. Considering that financial performance is an important part of economic strength, it can be inferred that companies with better financial performance are more motivated to improve their environmental accounting information disclosure quality.

Previous research has provided some evidence on the positive relationship between financial performance and the level of environmental information disclosure. For example, Ahmadi and Bouri's research on the top 40

* Corresponding author: 18811525286@163.com 
companies operating in France shows that the need for capital, profitability and capital spending, have a positive influence on environmental disclosure quality [8]. Armansyah's research for listed companies in the Indonesian mining industry finds that the better the company's financial liquidity and profitability, the higher the quality of environmental information disclosure [9]. Omnamasivaya's study also indicates that the environmental accounting information disclosure index is positively correlated with some financial indicators, such as ROE, ROA, EPS, and so on [10].

Based on the above discussion, this study believes that financial performance can promote the quality of environmental accounting information disclosure. According to China's financial analysis practice, financial performance includes four aspects: profitability, liquidity, operating ability and development ability. The higher the abilities in these four areas, the better the financial performance, the higher the EID. Accordingly, this paper proposes the hypothesis as below.

Hypothesis 1 . The financial performance is positively related to EID.

Since financial performance includes four aspects, Hypothesis 1 contains four sub-hypotheses:

Hypothesis 1a. Corporate liquidity is positively related to EID.

Hypothesis 1b. Corporate operating ability is positively related to EID.

Hypothesis 1c. Corporate profitability is positively related to EID.

Hypothesis 1d. Corporate development ability is positively related to EID.

\section{Data collection and model design}

\subsection{Data collection}

We carried out statistical analysis on the relevant data of 330 companies in the heavily polluting industry on the Shanghai Stock Exchange in 2017. The heavily polluting industries were classified according to the "Industry Classification Management Catalogue for Environmental Protection Inspection of Listed Companies" issued by the Ministry of Environmental Protection and the "Guidelines for Industry Classification of Listed Companies (2012 Revision)" issued by the CSRC. We collected annual financial reports, environmental reports, sustainable development reports, social responsibility reports and environmental, social and governance reports from the Shanghai Stock Exchange website and the companies' official website. The data of EID was calculated manually based on the five periodic reports, and other data was obtained from the CSMAR database and CNKI Statistical Yearbook. We used SPSS24.0 to process the data.

\subsection{Model design}

The calculation of EID is based on the authors' research published in ICEMEE 2020, and we uses content analysis to score different disclosure items [11]. The monetary information in the disclosure project is scored two points. Quantitative information in non-monetized information accumulates two points, and qualitative information accumulates one point. If a company discloses an environmental report, it will be counted as two points, and other forms of voluntary reports (except annual financial reports) will be counted as one point. If the voluntary report has been audited by a third-party agency, one point is added. For information that is not included in the scoring system disclosed by the company, qualitative information is scored 1 point, and quantitative information is scored 2 points.

This study believes that financial performance includes liquidity, operating ability, profitability and development capabilities, four indicators should be selected to represent the performance of these four aspects. There are many financial indicators that explain the four capabilities, and we used the following steps to select appropriate indicators. First of all, we filtered out the indicators with missing data, and then performed correlation tests on the remaining indicators to exclude indicators that were strongly correlated with other independent variables or control variables. Next, the remaining indicators were substituted into the regression equation for fitting tests. Finally, four commonly used indicators with high goodness-of-fit values were selected to measure financial performance. The indicator representing liquidity is net working capital (Debt). Current asset turnover rate (Operate) is used to measure operating ability. It is return on total assets (ROA) that quantifies profitability, and equity growth rate (Growth) quantifies development ability.

The control variables include regional economic development level (District), measured by per capita GDP ranking of the province where the company's registered address is located; company size (Size), measured by the logarithm of total assets at the end of the year; nature of ownership (Owner), which is a dummy variable that will be 1 if the enterprise is state-owned and 0 otherwise; equity concentration (Top5), measured by the sum of the top five shareholders' shareholding ratio; independent director ratio (Independence), which is the number of independent directors divided by the total number of directors. The level of regional economic development and the nature of equity may cause government pressure to affect EID. The company size mainly affects EID from the perspective of social attention and reputation pressure. Equity concentration and independent directors proportion may affect the decision-making procedure of environmental information disclosure by influencing the rights structure of shareholders and management.

We used Model 1 to examine the factors that affect the quality of environmental accounting information disclosure, and the equation is as follows. 


\section{Empirical result}

The descriptive statistics and correlation analysis results of the variables are shown in Table 1. The statistical results of EID reflect that the overall level of environmental disclosure quality in China is not high enough, and the disclosure quality varies greatly among enterprises. Regional GDP per capita ranks from 1 to 31, indicating that the samples have a balanced regional distribution. The minimum ratio of independent directors is 0.3 , implying that the sample companies have ensured that the proportion of independent directors accounts for more than one-third in accordance with the provisions of the CSRC. The correlation coefficients between the variables do not significantly exceed 0.5 , which means that there is no serious endogenous problem between the variables, and the next step of regression analysis can be performed.

Table 1. Descriptive statistics and correlation test.

\begin{tabular}{|c|c|c|c|c|c|c|c|c|c|c|}
\hline & EID & Debt & Operate & ROA & Growth & District & Size & Owner & Top5 & Independence \\
\hline EID & 1 & & & & & & & & & \\
\hline Debt & -0.135 & 1 & & & & & & & & \\
\hline Operate & 0.343 & -0.312 & 1 & & & & & & & \\
\hline ROA & -0.073 & 0.202 & 0.071 & 1 & & & & & & \\
\hline Growth & 0.057 & 0.046 & 0.061 & 0.224 & 1 & & & & & \\
\hline District & 0.118 & 0.077 & -0.015 & 0.021 & 0.056 & 1 & & & & \\
\hline Size & 0.550 & -0.322 & 0.361 & 0.006 & -0.062 & -0.028 & 1 & & & \\
\hline Owner & 0.331 & -0.140 & 0.219 & -0.214 & -0.071 & 0.103 & 0.286 & 1 & & \\
\hline Top5 & 0.109 & -0.157 & 0.095 & 0.179 & -0.013 & -0.121 & 0.382 & 0.122 & 1 & \\
\hline Independence & -0.025 & 0.015 & 0.001 & -0.027 & -0.027 & -0.026 & 0.035 & 0.028 & 0.059 & \\
\hline Observations & 330 & 330 & 330 & 330 & 330 & 330 & 330 & 330 & 330 & \\
\hline Max & 29.000 & 7.367 & 10.247 & 0.430 & 6.653 & 31.000 & 6.381 & 1.000 & 0.978 & 0.625 \\
\hline Min & 0.000 & -15.151 & 0.071 & -0.149 & -4.714 & 1.000 & 2.209 & 0.000 & 0.132 & 0.300 \\
\hline Mean & 11.903 & -0.088 & 1.733 & 0.057 & 0.156 & 12.061 & 3.898 & 0.512 & 0.549 & 0.376 \\
\hline S.D. & 6.230 & 1.389 & 1.140 & 0.064 & 0.562 & 8.966 & 0.638 & 0.501 & 0.158 & 0.056 \\
\hline
\end{tabular}

The significance test results of the equation are shown in Table 2, and the following conclusions can be drawn based on the data in the table. Net working capital is significantly and positively related to EID, indicating that Hypothesis 1a is supported. Companies with high debt solvency do not need to selectively disclose favorable environmental information in order to gain the trust of creditors, and lower financing costs also make companies less sensitive to environmental disclosure costs. The current asset turnover rate is significantly positively correlated with EID, thus Hypothesis $1 b$ is verified. Operating capability is one of the important measures of asset quality. The higher the operating efficiency of the asset, the smaller the financial risk and operating risk of the enterprise. In this case, companies tend to provide more voluntary information in order to win the favor of external investors. The growth rate of equity is significantly positively correlated with EID and Hypothesis 1d is verified. Development ability represents the future development prospects of an enterprise. Companies with good development ability are more inclined to disclose environmental information in order to shape a good corporate reputation and provide support for long-term development. Hypothesis 1c is not supported because the regression results show that ROA is significantly negatively correlated with EID. Similar results have also appeared in other empirical studies of environmental accounting $[12,13]$. This may be due to corporate managers chasing short-term profits and ignoring long-term development such as environmental protection behaviors. It may also be caused by that the company with better profits have more internal resources and does not need to attract investors through environmental information disclosure. Another possible explanation is that listed companies with poor profitability may disclose excessive environmental information in order to divert the attention of stakeholders. In summary, Hypothesis 1 is only partially correct based on our regression results because there is no significant positive correlation between profitability and EID. In addition to profitability, the other three aspects of financial performance: development ability, liquidity, and operating ability all have a positive impact on EID.

Table 2. Regression result.

\begin{tabular}{|c|c|c|}
\hline & $\boldsymbol{\beta}$ & Sig. \\
\hline Debt & 0.438 & 0.047 \\
\hline Operate & 0.887 & 0.001 \\
\hline ROA & -8.425 & 0.076 \\
\hline Growth & 1.072 & 0.032 \\
\hline District & 0.068 & 0.029 \\
\hline Size & 5.077 & 0.000 \\
\hline
\end{tabular}




\begin{tabular}{|c|c|c|}
\hline Owner & 1.853 & 0.002 \\
\hline Top5 & -3.058 & 0.115 \\
\hline Independence & -4.642 & 0.336 \\
\hline Constant & -7.420 & 0.004 \\
\hline F-value & \multicolumn{2}{|c|}{23.080} \\
\hline Adjusted R $\mathbf{R}^{\mathbf{2}}$ & \multicolumn{2}{|c|}{0.377} \\
\hline
\end{tabular}

\section{Conclusion}

In order to explore the impact of financial performance on environmental accounting information disclosure quality, this article used the 2017 data of listed companies in the heavily polluting industry of the Shanghai Stock Exchange in China as a sample for regression testing. The regression result of Model 1 shows that, except the return on assets, the other three indicators of financial performance - net working capital, current asset turnover and equity growth rate, are significantly positively correlated with EID. This means that the solvency, operating ability and development ability in financial performance can play a positive role in promoting environmental disclosure quality, but profitability cannot. This may be due to the short-term profit-seeking behavior of management, or companies with sufficient profits are reluctant to attract investors through environmental disclosure and companies with poor profits may confuse investors by disclosing too much environmental information.

\section{Acknowledgement}

The authors acknowledge the National Social Science Foundation of China (Grant: 19BGL011).

\section{References}

1. Mata, C., Fialho, A. \& Eugénio, T. (2018), "A decade of environmental accounting reporting: What we know?", Journal of Cleaner Production, Vol. 198, pp. 1198-1209.

2. Clarkson, P. M., Li, Y., Richardson, G. D. \& Vasvari, F. P. (2008), "Revisiting the relation between environmental performance and environmental disclosure: An empirical analysis", Accounting, Organizations and Society, Vol. 33, pp. 303-327.

3. Luo, W., Guo, X., Zhong, S. \& Wang, J. (2019), "Environmental information disclosure quality, media attention and debt financing costs: Evidence from Chinese heavy polluting listed companies", Journal of Cleaner Production, Vol. 231, pp. 268-277.

4. Perera, L., Jubb, C. \& Gopalan, S. (2019), "A comparison of voluntary and mandated climate change-related disclosure", Journal of Contemporary Accounting \& Economics, Vol. 15 No. 2, pp. 243266.

5. Li, D., Cao, C., Zhang, L., Chen, X., Ren, S. \& Zhao, Y. (2017), "Effects of corporate environmental responsibility on financial performance: The moderating role of government regulation and organizational slack", Journal of Cleaner Production, Vol. 166, pp. 1323-1334.

6. Guidry, R. P. \& Patten, D. M. (2012), "Voluntary disclosure theory and financial control variables: An assessment of recent environmental disclosure research", Accounting Forum, Vol. 36 No. 2, pp. 8190.

7. Qiu, Y., Shaukat, A. \& Tharyan, R. (2016), "Environmental and social disclosures: Link with corporate financial performance", The British Accounting Review, Vol. 48 No. 1, pp. 102-116.

8. Ahmadi, A. \& Bouri, A. (2017), "The relationship between financial attributes, environmental performance and environmental disclosure", Management of Environmental Quality: An International Journal, Vol. 28 No. 4, pp. 490-506.

9. Armansyah, R. F. (2018), "Do financial performance affect the environmental performance and environmental disclosure? With sem-pls. Case: indonesian stock exchange", ISJ Theoretical \& Applied Science, Vol. 10 No. 66, pp. 12-20.

10. Omnamasivaya, B. \& Prasad, M. S. V. (2017), "Does financial performance really improve the environmental accounting disclosure practices in India: An empirical evidence from nifty companies", African J. Economic and Sustainable Development, Vol. 6 No. 1, pp. 52-66.

11. Shen, J. \& Chen, Y. (2020), "A Comparative Study of Environmental Accounting Information Disclosure between China and Developed Countries", IOP Conference Series: Earth and Environmental Science, Vol. 508, pp. 012011.

12. Smith, M., Yahya, K. \& Amiruddin, A. H. (2007), "Environmental disclosure and performance reporting in Malaysia", Asian Review of Accounting, Vol. 15 No. 2, pp. 185-199.

13. Ho, L., \& Taylor, M. E. (2007), "An empirical analysis of triple bottom-line reporting and its determinants: Evidence from the United States and Japan", Journal of International Financial Management and Accounting, Vol. 18 No. 2, pp. 123150. 